Farmers in Rebellion 
THIS PAGE INTENTIONALLY LEFT BLANK 


\title{
Farmers in Rebellion
}

The Rise and Fall of the Southern Farmers Alliance and People's Party in Texas

\author{
By Donna A. Barnes
}

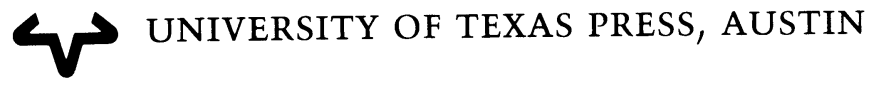


Publication of this book was assisted by a grant from The Littlefield Fund for Southern History, The University of Texas at Austin.

Copyright $(\mathcal{1}) 884$ by the University of Texas Press All rights reserved

Printed in the United States of America

First edition, I984

Requests for permission to reproduce material from this work should be sent to:

Permissions

University of Texas Press

Box 78 I 9

Austin, Texas 787 I 3

LIBRARY OF CONGRESS CATALOGING IN PUBLICATION DATA

Barnes, Donna, I954-

Farmers in rebellion.

Bibliography: $p$.

Includes index.

I. People's Party (Texas)-History-igth century.

2. National Farmers' Alliance and Industrial UnionHistory - I9th century. 3. Populism-Texas-HistoryI9th century. I. Title.

JK2374.T4B3 I $985 \quad 324.2764^{\prime} \mathrm{O} 2 \quad 84$-IO373

ISBN 0-292-77030-8 
To my father, who left me with many special memories 
THIS PAGE INTENTIONALLY LEFT BLANK 